\title{
IMPLEMENTASI ARCHITECTURE FOR ALL PADA PEMANFAATAN RUANG TERBUKA HIJAU SEBAGAI RUANG TUNGGU DI KANTOR PEMERINTAHAN
}

\author{
Friska Hasibuan ${ }^{1}$, Samsu Hendra Siwi ${ }^{2}$ \\ ${ }^{1}$ Mahasiswa Program Studi Magister Arsitektur Universitas Tarumanegara, Jakarta \\ Email: friscahasb@gmail.com \\ ${ }^{2}$ Staf Pengajar Program Studi Magister Arsitektur Universitas Tarumanegara, Jakarta \\ Email: sh.siwi@gmail.com
}

\begin{abstract}
ABSTRAK
Artikel ini berisi tentang implementasi arsitektur untuk semua pada pemanfaatan ruang terbuka sebagai ruang tunggu bagi masyarakat yang berkepentingan/ pengurusan perijinan pada Kantor Walikota Administrasi Jakarta Barat. Kantor Walikota merupakan salah satu wujud kantor pemerintahan sebagai penyedia layanan publik yang tidak terlepas dari ketersediaan ruang tunggu pelayanan, baik ruang tunggu di dalam kantor maupun di luar ruangan/ ruang terbuka publik. Aktifitas menunggu di ruang terbuka berada diantara beberapa bangunan dengan fungsi berbeda, yakni diantara gedung walikota (PTSP), bangunan parkir, bangunan kantin, taman, Bank DKI. Masyarakat berkumpul pada pada bahu taman, di depan minimarket, di pinggiran selasar dan pinggiran taman dengan beragam aktifitas yang menyebabkan dan menimbulkan keramaian tidak pada tempatnya dan secaar visual mengganggu estetika. Dalam ha ini dapat diidentifikasi butuhnya pengolahan ruang terbuka hijau sebagai sarana ruang tunggu guna peningkatan pelayanan di kantor Pemerintahan. Penerapan pengolahan ruang luar secara arsitektural, mengimplementasikan ilmu arsitektur dapat mengakomodir kebutuhan manusia, penataan lingkungan, bangunan dan penambahan elemen sarana prasarana dapat mencerminkan bahwa arsitektur adalah untuk semua, bukan hanya kalangan tertentu dan kawasan tertentu. Metode yang digunakan adalah deskritif kualitatif sehingga menggambarkan analisa keadaan dan kebutuhan pada area terpilih dan dapat disimpulkan bahwa penataan secara arsitektural meberi nilai lebih baik untuk kawasan dan peningkatan kepuasan masyarakat.
\end{abstract}

Kata Kunci: kantor pemerintahan, ruang tunggu, ruang terbuka, ruang publik

\section{Abstract}

This article is about the implementation of architecture for all on the use of open space as a waiting room for people who have an interest / management of permits at the West Jakarta Administration Mayor's Office. The Mayor's Office is one form of a government office as a public service provider that is inseparable from the availability of service waiting rooms, both waiting rooms in the office and outdoors / public open spaces. Open waiting activities are among several buildings with different functions, namely between the mayor building (PTSP), parking buildings, canteen buildings, parks, Bank DKI. People gather on the shoulders of the park, in front of the minimarket, on the outskirts of the lobby and the edge of the park with a variety of activities that cause an inappropriate place and visually disrupt aesthetics. In this case we can identify the processing of green open spaces as a means of waiting space improving services in Government offices. The application of architectural outer space processing, implementing architectural science can accommodate human needs, environmental management, building and adding elements of infrastructure can reflect that architecture is for all, not just certain circles and spesific regions. The method used is descriptive qualitative so that it describes the analysis of the conditions and needs of the selected area and it can be concluded that architectural arrangement gives better values for the region and increased community satisfaction.

Keywords: government offices, waiting rooms, open spaces, public space

\section{PENDAHULUAN}

\section{Latar belakang}

Arsitektur untuk semua merupakan cerminan bahwa bidang ilmu arsitektur dipengaruhi dan mempengaruhi banyak hal maupun bidang ilmu lain dan memberi dampak untuk 
meningkatkan lingkungannya. Menurut Vitruvius, "Arsitektur adalah ilmu yang timbul dari ilmu-ilmu lainnya, dan dilengkapi dengan proses belajar, dibantu dengan penilaian terhadap karya tersebut sebagai karya seni. Peran arsitektur bukan saja berguna untuk manusia dan ruangnya, tetapi berbicara bidang ilmu ini juga bisa diterapkan dalam alam, perilaku, lingkungan, teknologi, iklim, material dan banyak hal lainnya yang berguna untuk kehidupan yang berkelanjutan.

Penerapan bidang ilmu arsitektur dalam artikel ini berbicara ruang tunggu pada kantor pemerintahan, dimana ruang tunggu yang nyaman sebagai pelayanan publik yang sangat penting dalam berjalannya roda penyelenggaraan pemerintahan. Ilmu Arsitektur memandang ruang tunggu sebagai faktor pendukung kenyamanan publik bukan saja merupakan suatu ruang publik di dalam bangunan tetapi bisa terdapat di ruang terbuka di sekitar tempat pelayanan publik diselenggarakan. Ruang terbuka hijau pada eksisting lingkungan bangunan pemerintahan selain berguna bagi pegawai di kantor pemerintahan juga dapat dimaksimalkan fungsinya bagi pelayanan masyarakat. Carmona (2003) menyatakan ruang terbuka publik merupakan ruang yang dapat memberikan kesempatan rekreasi, lingkungan alamiah, tempat untuk mengadakan acara khusus dan ruang untuk kota bernafas. Pada skala yang lebih besar ruang terbuka publik harus dapat menciptakan hubungan antara manusia dengan alam. Untuk skala yang lebih kecil biasanya standar ruang terbuka publik ditetapkan oleh pemerintah setempat. Menurut (Carmona, 2003) ada Tiga esensi ruang publik yakni Meaningful (dapat memberikan makna atau arti bagi masyarakat setempat secara individual maupun kelompok), Responsive (tanggap terhadap semua keinginan pengguna dan dapat mengakomodir kegiatan yang ada pada ruang publik tersebut), Democratic (dapat menerima kehadiran berbagai lapisan masyarakat dengan bebas tanpa ada diskriminasi) agar menjadi pedoman ketersediaan ruang publik. Ruang publik dapat berupa ruang terbuka, pengaturan tentang ruang terbuka juga telah diatur tersendiri. Ruang terbuka tidak hanya berfungsi untuk mengembangkan interaksi sosial dalam sebuah kawasan, tetapi juga berperan penting dalam menjaga sistem ekologis lingkungan secara keseluruhan di samping mendukung terbentuknya unsur estetis lingkungan (Hidayah, 2012).

Kantor Walikota Jakarta Barat, sebagai salah satu kantor Pemerintahan yang melayani masyarakat mempunyai tugas dan fungsi memberikan pelayanan terbaik untuk masyarakat dan pengguna gedung, baik di dalam gedung maupun di luar gedung yang dapat digunakan sebagai sarana dan prasarana menunjang pelayanan tersebut. Fenomena masyarakat yang berkumpul pada titik tertentu untuk menunggu dan bersosialisasi menjadikan adanya suatu ruang tunggu terbuka dan ruang bersosialisasi yang secara tidak sengaja terjadi. Aktifitas menunggu di ruang terbuka pada kantor walikota Jakarta Barat menimbulkan fenomena bahwa ada satu titik simpul pada area publik dipinggir taman terbuka yang dijadikan menjadi ruang tunggu bagi para pengguna kepengurusan pada kantor walikota. Hal ini terjadi pada ruang terbuka yang menjadi konektor antara gedung pemerintahan, ruang parkir, minimarket dan taman, terutama pada jam pelayanan tinggi mengakibatkan suasana yang ramai (crowded), menggangu secara visual dengan aktifitas diantaranya duduk- duduk di pinggiran bahu taman dan di sisi selasar serta taman dengan beragam kegiatan. Disamping itu terdapat Ruang Terbuka Hijau yang dapat diolah menjadi ruang bersosialisasi yang lebih baik jika ditata secara maksimal sehingga dapat mengakomodir kegiatan menunggu.

\section{Perumusan masalah}

Adanya ruang terbuka hijau yang tersedia pada Kawasan Kantor Walikota Jakarta Barat yang dapat ditata sedemikian rupa untuk mengakomodir ruang sosialisasi masyarakat yang melakukan pengurusan di Kantor Pemerintahan yang merupakan bagian dari pelayanan 
masyarakat. Namun saat ini, ada area tertentu yang mengalami disfungsi dan beralih fungsinya menjadi ruang tunggu yang jika dibiarkan maka bagian /titik simpul ini akan berkembang jadi ruang yang tidak terurus sehingga merusak citra kantor pemerintahan dan menghambat kelancaran pelayanan kepada masyarakat. Masalah-masalah yang dapat dirumuskan untuk dijawab antara lain: Bagaimana pengaruh dan fungsi ruang terbuka terhadap perletakan bangunan utama dan bangunan pendukung pada kantor walikota Jakarta Barat, Elemen apa yang dapat mendukung aktifitas masyarakat pada saat menunggu di ruang terbuka pada kantor walikota Jakarta Barat, Bagaimana pertumbuhan ruang terbuka dengan adanya fungsi ruang sebagai ruang tunggu, dan apakah ada pengaruh ruang terbuka hijau dan pola perilaku masyarakat terhadap tumbuhnya ruang tunggu terbuka.

\section{METODE}

Artikel ini menggunakan metode penelitian deskriptif kualitatif yakni menggambarkan secara rinci mengenai objek yang akan diteliti. Teknik pengumpulan data yang digunakan penulis yakni dengan observasi dan wawancara dengan orang-orang yang berkaitan dengan artikel ini. Pada penelitian ini penulis menggambarkan dan menganalisis penyebab tumbuhnya titik kumpul sebagai sarana menunggu pada ruang terbuka dan implementasi arsitektur untuk semua pada ruang terbuka hijau yang berada di Kantor Walikota Jakarta Barat.

\section{Sumber data}

Dalam penelitian ini penulis mengguanakan dua sumber data sebagai sumber data penelitian, yakni data primer dan data sekunder.Berdasarkan data primer, yakni wawancara dengan beberapa orang yang menunggu pada ruang terbuka, bahwa mereka mengambil posisi karena dekat dengan gedung bidang perijinan dan bisa menunggu giliran antriannya tanpa harus di dalam ruang dan view yang bagus ke arah taman serta sambil bersosialisasi. Data sekunder didapat dari sumber buku dan literatur.

\section{PEMBAHASAN}

Lokasi penelitian berada di Kantor Walikota Jakarta Barat, dengan batas- batas wilayah:

Timur : Berbatasan dengan jalan Puri Asri dan gedung Hypermart.

Selatan: Berbatasan dengan jalan Puri Indah Raya dan Bangunan Lippo Mall Puri.

Barat : Berbatasan dengan jalan Puri Wangi dan Apartment The Windsor Kembangan

Utara : Berbatasan dengan jalan Kembangan Raya dan Bangunan Kejaksaan Negeri

Letak ruang publik berada diantara gedung kantor, bangunan parkir, bangunan kantin dan Bank DKI serta keberadaan taman dan ruang terbuka publik.
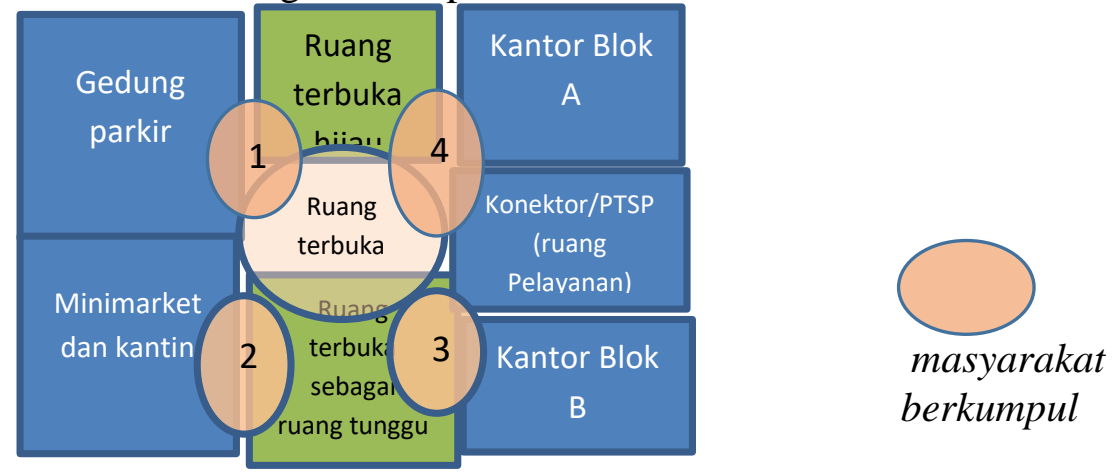

Gambar 1. Pola perletakan masyarakat menunggu pada ruang terbuka di kantor pemerintahan. 
Ruang terbuka pada gambar 1. di atas dikelilingi oleh bangunan kantor Walikota blok A dan bangunan blok B, minimarket, gedung parkir, kantin dan titik simpul berada di tengah tengah bangunan tersebut. Pola bangunan yang mengelilingi ruang terbuka tersebut memberi pengaruh terhadap tumbuhnya tempat sosialisasi dan kegiatan menunggu di area tersebut. Sehingga menurut pengamatan bahwa ruang terbuka hijau diantara banyak bangunan memberi fungsi ganda pada ruang terbuka tersebut, dpat dilihat dengan masyarakat yang beraktifitas disana.
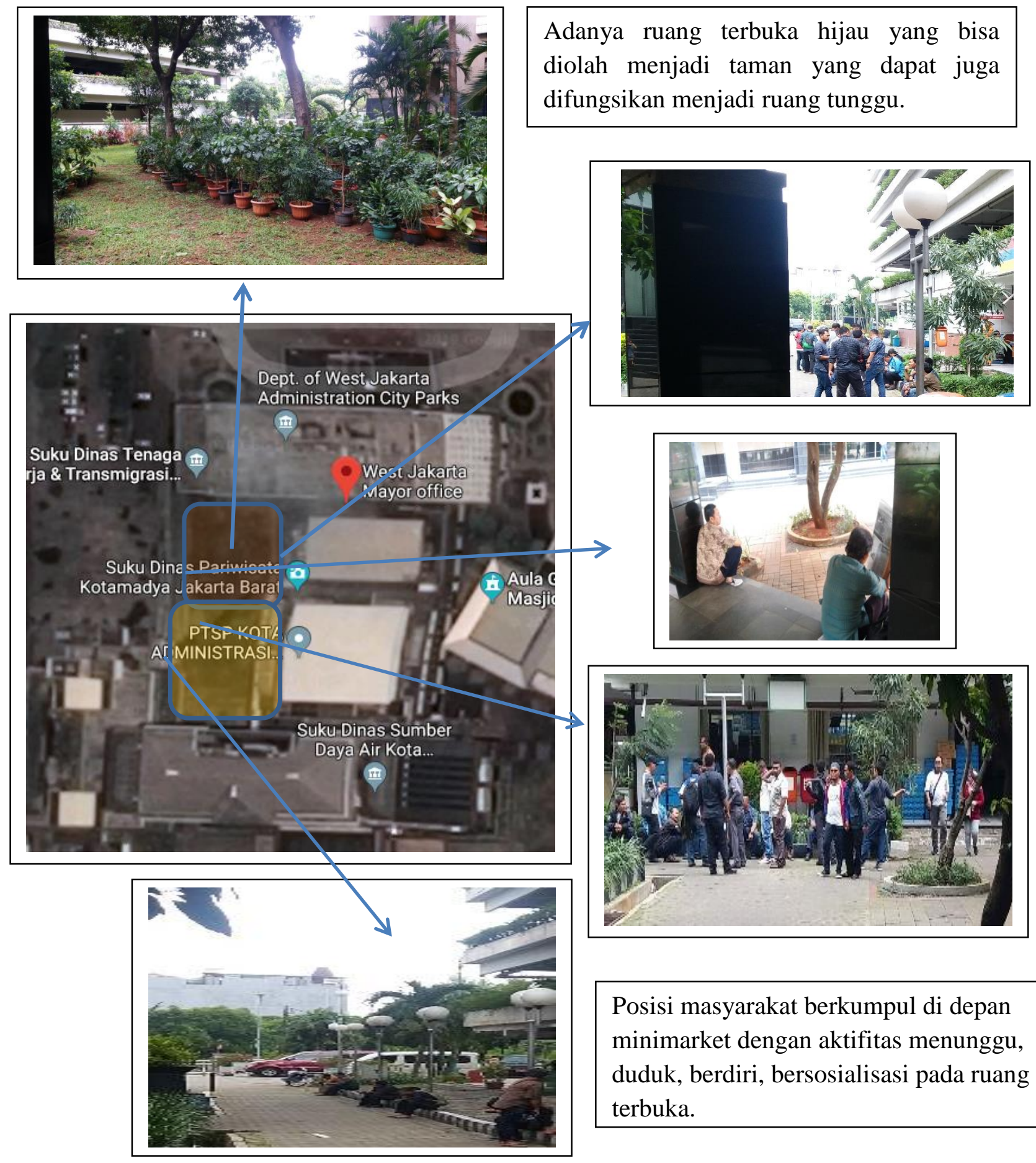

Posisi masyarakat berkumpul di depan minimarket dengan aktifitas menunggu, duduk, berdiri, bersosialisasi pada ruang terbuka.

Gambar 2. Kondisi eksisting ruang terbuka diantara beberapa bangunan sebagai ruang tunggu 
Aktifitas masyarakat sambil menunggu dengan posisi berdiri dan duduk di bahu taman, ada yang bersenda gurau, membenahi berkas, merokok dan mengambil posisi di pinggiran taman. Sesuai dengan defenisinya bahwa Ruang terbuka (Open Space) merupakan ruang terbuka yang selalu terletak di luar massa bangunan yang dapat dimanfaatkan dan dipergunakan oleh setiap orang serta memberikan kesempatan untuk melakukan bermacam-macam kegiatan (Hakim, 2003 : 50). Dari segi arsitektur, suasana ruang terbuka publik sangat terasa dan akan lebih berhasil jika diolah dengan menambah sarana prasarana yang mendukung runag terbuka ini. Sesuai dengan esensi ruang publik yakni Meaningful (dapat memberikan makna atau arti bagi masyarakat setempat secara individual maupun kelompok ) dan Democratic (dapat menerima kehadiran berbagai lapisan masyarakat dengan bebas tanpa ada diskriminasi) menurut Carmona( 2003). Menurut pengamatan di lapangan, aktifitas lain adalah duduk- duduk sambil bercerita, membaca koran, terkadang minum dan makan makanan ringan pada selasar mengarah ke ruang terbuka hijau maupun plasa. Esensi ruang public Responsive (tanggap terhadap semua keinginan pengguna dan dapat mengakomodir kegiatan yang ada pada ruang publik tersebut). Menurut Carmona ( 2003) belum terasa dan belum terakomodir karena keinginan akan ruang atau tempat duduk belum tersedia pda ruang public di kawasan ini, sehingga kegiatan bersosialisasi mengambil tempat di bahu taman dan koridor.

Tersedianya ruang terbuka hijau dan ruang terbuka berupa plasa yang merupakan ruang terbuka publik pada kantor walikota Jakarta Barat. Ruang terbuka ini berada diantara bangunan dan belum tersedianya prasarana seperti tempat duduk dan prasarana lain untuk mengakomodir masyarakat yang berkumpul dan menunggu di tepi ruang terbuka tersebut. Menurut Cooper (1998 : 23) menyatakan bahwa "ukuran utama keberhasilan dari ruang publik adalah pemanfaatannya, sedangkan pemanfaatan dan kepopuleran sebuah ruang publik tergantung lokasi dan detail dalam rancangannya". Implementasi arsitektur dalam hal ini keduanya harus lebih terkomunikasikan yaitu keterkaitan antara rancangan setting fisik dengan pemanfaatan ruang publik, sehingga ruang publik tersebut memiliki daya tarik tersendiri bagi masyarakat untuk memanfaatkan dan beraktivitas di dalam ruang publik tersebut.

Tabel 1. Pengamatan waktu, jenis aktifitas dan frekwensi kegiatan oleh pelaku

\begin{tabular}{|c|c|c|c|c|}
\hline Hari & Waktu & Jenis aktifitas & Frekuensi kegiatan & Pelaku Kegiatan \\
\hline \multirow{15}{*}{$\begin{array}{l}\text { senin s/d } \\
\text { jumat }\end{array}$} & \multirow{5}{*}{$\begin{array}{l}p k l 8.00- \\
11.00\end{array}$} & merokok & \multirow{5}{*}{ sedang } & \multirow{5}{*}{$\begin{array}{c}\text { Dewasa pria dan } \\
\text { wanita, anak- anak } \\
\text { jarang }\end{array}$} \\
\hline & & bersosialisasi & & \\
\hline & & membenahi berkas & & \\
\hline & & menunggu & & \\
\hline & & duduk- duduk & & \\
\hline & \multirow{5}{*}{$\begin{array}{l}\text { pkl 11.00- } \\
14.00\end{array}$} & merokok & \multirow{5}{*}{ padat } & \multirow{5}{*}{$\begin{array}{c}\text { Dewasa pria dan } \\
\text { wanita, anak- anak } \\
\text { jarang }\end{array}$} \\
\hline & & bersosialisasi & & \\
\hline & & membenahi berkas & & \\
\hline & & menunggu & & \\
\hline & & duduk- duduk & & \\
\hline & \multirow{5}{*}{$\begin{array}{c}p k l 14.00- \\
16.00\end{array}$} & merokok & \multirow{5}{*}{$\begin{array}{c}\text { sedang cenderung mulai } \\
\text { sepi }\end{array}$} & \multirow{5}{*}{$\begin{array}{c}\text { Dewasa pria dan } \\
\text { wanita, anak- anak } \\
\text { jarang }\end{array}$} \\
\hline & & bersosialisasi & & \\
\hline & & membenahi berkas & & \\
\hline & & menunggu & & \\
\hline & & duduk- duduk & & \\
\hline
\end{tabular}




\section{Keberhasilan ruang terbuka publik dan implementasi arsitektur untuk semua}

1. Aksesibilitas, Project for Public Spaces, 2004, menyatakan akses merupakan hal yang penting dalam keberhasilan ruang terbuka publik, yaitu kemudahan ruang terbuka publik untuk didatangi dan mudah dilihat. Carr, et al, (1992) menyatakan ruang terbuka publik haruslah demokratis, ruang tersebut dapat diakses semua golongan, mudah diakses secara fisik maupun visual. Miller (2009), menyatakan bahwa ruang tersebut aman, yang ditandai dengan mudahnya penglihatan dari luar ataupun ke dalam taman, mudah didatangi dan terbuka.
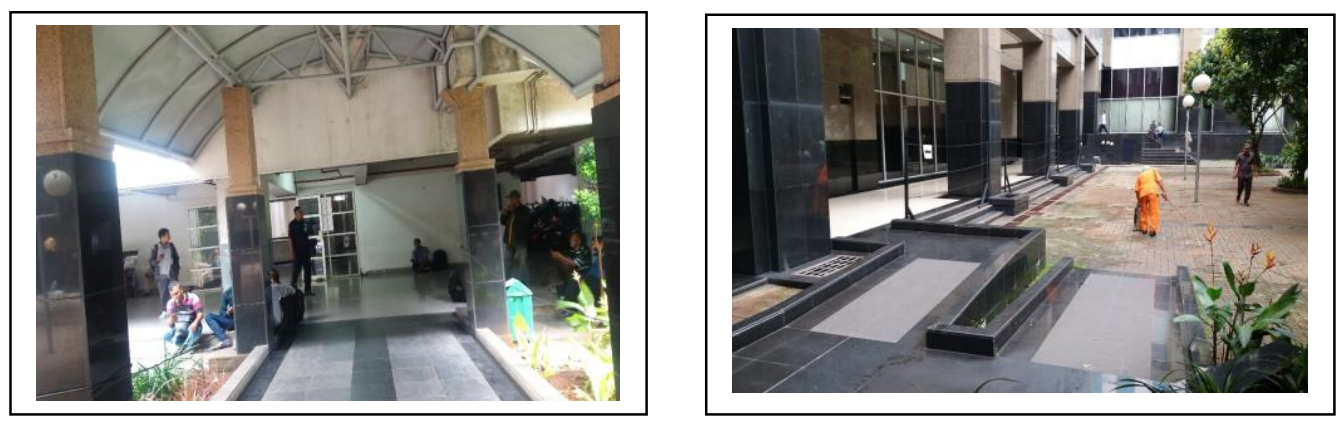

Gambar 3. Aksesibilitas masyarakat melalui koridor dan ruang terbuka di kantor Walikota Jakarta Barat

Ruang terbuka sebagai ruang tunggu merupakan area dengan aksesibitas tinggi seperti pada gambar 3. yang merupakan ruang terbuka dilalui dan diapit oleh bangunan kantor, gedung parkir, minimarket dan taman serta adanya jalur difabel, sehingga untuk area termasuk berhasil dari segi aksesibilitas, tetapi menjadi jalur sirkulasi menjadi terganggu ketika masyarakat duduk berdiri di pinggiran selasar jalan yang mengelilingi ruang terbuka ini. Pemberian jalur pedestrian, area hijau, sarana duduk dan bersosialisasi menjadi sarana untuk menunjang aksesibilitas yang optimal. Elemen sarana aksesibilitas yang direkomendasikan sesuai dengan konsep arsitektural yang menerapkan firmitas yaitu soliditas/kekokohan, venustas (keindahan) dan utilitas (fungsional) (Vitruvius, 10 books on architecture).

2. Kesenangan dan menarik pengguna, Carr et al (1992) menyatakan ruang publik haruslah responsif, yaitu dapat menjawab kebutuhan pengguna dalam hal ini aktivitas aktif dan pasif yang dapat memberikan kesenangan. Project for Public Spaces (2004) menjadikan aktivitas dan penggunaan menjadi kriteria ruang terbuka publik yang berhasil, tentunya dengan adanya aktivitas maka ruang tersebut dapat memberikan kesenangan dan akan menarik pengguna. Miller (2009) menyatakan ruang tersebut dapat memenuhi kebutuhan pengunjungnya dalam beraktivitas yang dapat memberikan kesenangan.
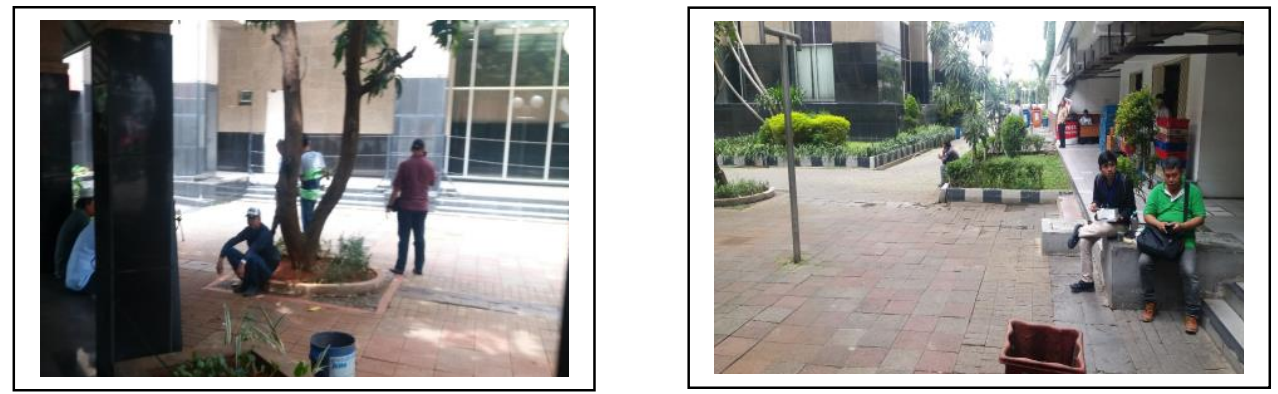

Gambar 4. Masyarakat menunggu dengan duduk di bahu taman dan koridor 
Ruang terbuka yang berhasil dari segi kesenangan pengguna belum terasa pada area ini, karena masyarakat, duduk dipinggiran pohon, tidak ada sarana bangku yang mendukung dan berdiri begitu saja sehingga merusak pemandangan dan tinjauan kepada pelayanan masyarakat dari segi memberi kesenenangan belum tercapai. Keadaan sarana dan prasarana penyelenggarakan pelayanan publik yang belum terpenuhi secara lancar bagi kepentingan urusan pelayanan. Belum terpenuhinya tempat pelayanan dengan sarana ruang tunggu/tamu serta belum ditunjang dengan fasilitas-fasilitas yang dapat menciptakan suasana nyaman bagi pemohon pelayanan.

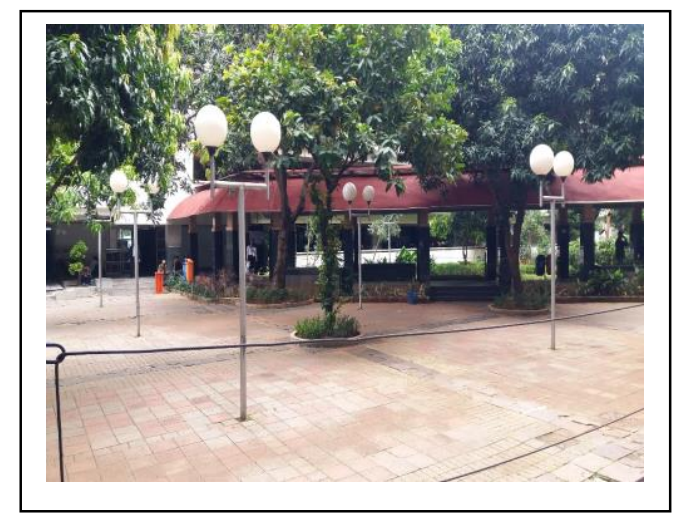

Gambar 5. Ruang terbuka hanya bermaterial konblok tanpa ada sarana seperti tempat duduk untuk masyarakat di kantor Walikota Jakarta Barat

Untuk area ini, Berdasarkan Permen PU No. 12 Tahun 2009 bahwa RTNH merupakan penunjang dari suatu fungsi bangunan seperti plasa, tempat bermain, tempat berolahraga dan parkir yang dapat menampung aktivitas masyarakat di sekitarnya, Konsep pengembangan ruang terbuka publik di lokasi ini adalah dengan mengintegrasikan ruang terbuka hijau dengan ruang terbuka nonhijau. Adapun aspek yang diperhatikan dalam perancangannya adalah Elemen fisik dan elemen non fisik. Elemen Fisik merupakan elemen pembentuk space dalam arsitektur yang berupa wujud seperti massa bangunan, furniture, perabotan, penginderaan dan lainnya. Dalam studi kasus, hal ini diterapkan pada penataan taman sebagai ruang tunggu dan sarana prasarana pendukungnya yang disesuaikan dengan perilaku masyarakat pengguna. Sedangkan elemen nonfisik dari segi kenyamanan dan kenyamanan tentu belum didapati jika sarana belum tersedia. Pengolahan dan rancang ulang RTH dan RTNH yang berada tepat pada posisi masyrakat berkumpul didukung dengan kelengkapan prasarananya diharapkan dapat mencapai keberhasilan ruang terbuka ini.

3. Keamanan dan kenyamanan, Miller (2009), ruang publik haruslah aman, dengan amannya sebuah ruang maka ruang tersebut dapat terus dikunjungi dan berfungsi dengan baik. Carr et al (1992) menyatakan ruang publik haruslah responsif yaitu dapat memberikan kenyamanan kepada masyarakat. Project for Public Spaces (2004), menjadikan kenyamanan sebagai kriteria yang penting bagi sebuah ruang, ruang yang nyaman ditandai dengan ruang yang bersih dan aman. Menurut pengamatan dan hasil wawancara bahwa kondisi crowded pada area ini tidak memberikan kenyaman dan keamanan untuk menunggu, hanya dianggap sebagai area paling tepat untuk menuggu oleh masyarakat, walaupun tidak ada sarana prasarana memadai. Apabila dilengkapi dengan sarana dan prasarana maka menurut hasil wawancara masyarakat akan lebih nyaman dan menyambut gembira untuk ketersediaan prasarana tersebut. adanya lokasi khusus bagi pria dengan adanya titik smoking area dan 
alokasi menyediakan sarana tanaman bunga- bungaan pada konsep penataan taman yang disukai oleh kaum perempuan.
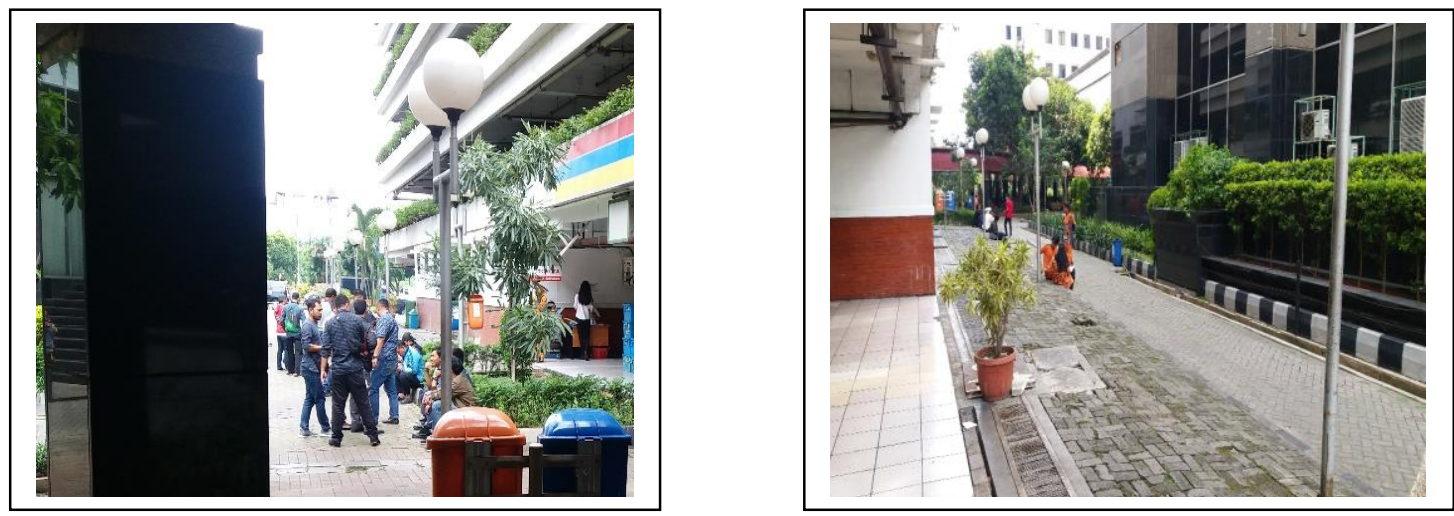

Gambar 6. Perilaku masyarakat untuk duduk mengambil posisi dekat dengan bangunan di kantor Walikota Jakarta Barat

Selain itu disediakan jalur disabilitas untuk menghadirkan kenyamanan pada kaum difabel, dengan elemen pedestrian khusus pada ruang terbuka dengan konsep perancangan yang sesuai dengan aturan disabilitas yang berlaku. Penerapan konsep perencanaan penataan ruang terbuka hijau, dengan menghadirkan suasana, spirit, emosi pada ruang terbuka pada Kantor Walikota Jakarta Barat diharapkan tujuan untuk mencapai kenyamanan masyarakat dapat dicapai. Dari hasil wawancara dan pengamatan bahwa makna ruang terbuka dari segi kenyamanan belum diperoleh dari area ini.

4. Mengikat masyarakat, Carr et al (1992), menyatakan ruang publik harus memiliki makna dan keterkaitan bagi masyarakat, ruang yang bermakna dan memiliki keterikatan akan ditandai dengan adanya rasa kepedulian dari masyarakat pada ruang tersebut. Project for Public Spaces (2004) menyatakan keramahan merupakan hal yang penting ada pada ruang terbuka publik yang ditandai dengan adanya keterikatan masyarakat dengan ruang publik tersebut. Untuk Area terpilih merupakan ruang publik yang sudah mengikat masyarakat karena merupakan ruang terbuka public di area pemerintahan yang terbuka untuk masyarakat, namun penataannya menurut pengamatan butuh ditata lebih lagi. Salah satu tujuan penataan adalah dapat menyediakan tempat duduk bagi masyarakat untuk bersosialisasi. Hal ini dapat diciptakan dengan merancang "titik kumpul" untuk masyarakat. Contohnya seperti penataan perletakan bangku yang dibuat melingkar, dan sebagainya.Walaupun di ruang terbuka namun keberadaan ruang bisa dirasa dengan tempat yang melingkar, sehingga toleransi dan keakraban dapat dirasakan masyarakat.
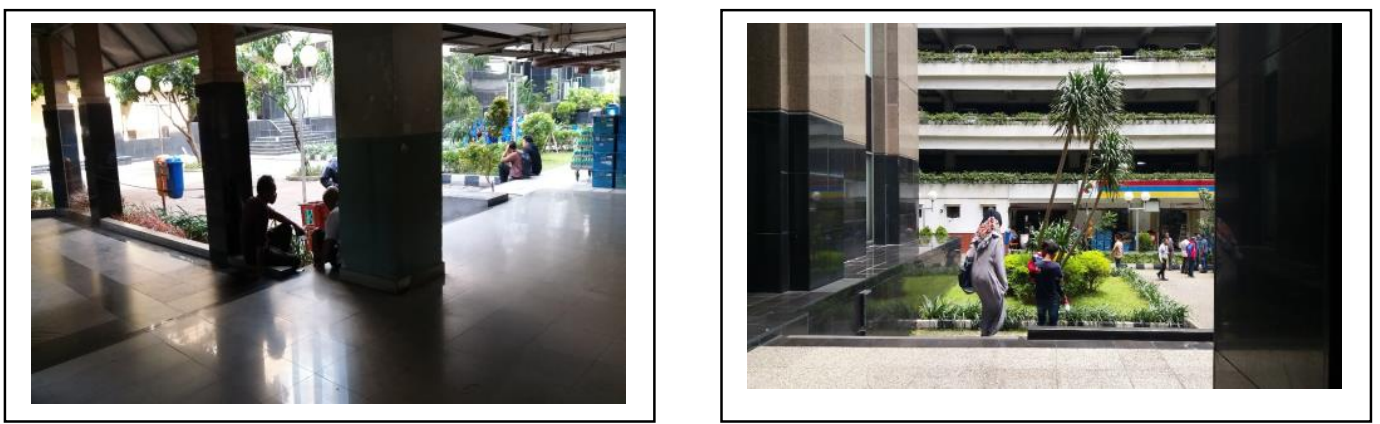

Gambar 7. Menunggu sambil bersosialisasi di tempat sirkulasi 


\section{KESIMPULAN DAN SARAN}

Dari analisa diatas dapat disimpulkan adanya pengaruh fungsi ruang terbuka terhadap perletakan bangunan utama dan bangunan pendukung sebagai tempat simpul sirkulasi lintas bangunan. Jarak yang saling berdekatan antar bangunan memberi pengaruh terhadap ruang terbuka hijau ditengah bangunan- bangunan tersebut, disamping pola perilaku masyarakat yang juga memberi pengaruh terhadap ruang tunggu terbuka. Ruang terbuka digunakan sebagai tempat berkumpul dan menunggu masyarakat di Kantor Walikota Jakarta Barat, digunakan sebagai alternatif ruang tunggu bagi masyarakat. Kenyamanan ruang tunggu dapat diperoleh antara lain dengan pengaturan elemen seperti pendukung ruang hijau, penambahan tempat duduk dan penataan ruang terbuka yang dapat mendukung aktifitas masyarakat pada saat menunggu. Keberhasilan ruang terbuka dapat dirasakan dengan memaksimalkan ruang terbuka sebagai ruang tunggu. Diharapkan masyarakat tidak saja merasa puas dari segi pelayanan yang di berikan kantor Walikota Jakarta Barat dalam aspek menangani setiap keluhan masyarakat, namun juga merasa nyaman dengan tersedianya taman yang tertata sebagai pendukung sarana ruang tunggu terbuka yang nyaman, aman dan memberikan kesan yang menyenangkan. Pola perilaku masyarakat yang suka berkumpul dan beraktifitas pada area yang dilingkupi beberapa bangunan dengan fungsi yang berbeda menunjukkan adanya kaitan antara perilaku masyarakat dengan ketersediaan ruang untuk menunggu. Ilmu arsitektur digunakan dalam menata ulang, mengidentifikasi kebutuhan pengguna, baik masyarakat, ruang pelingkup, tanaman dan elemen pendukung serta solusi sesuai kebutuhan pengguna. Penerapan ilmu dalam analisa dan solusi juga mencerminkan Architecture for all. Tidak hanya manusia atau golongan tertentu yang merasakan penerapan ilmu rancang arsitektural, tetapi lingkungan, aturan peraturan, bahkan ilmu bidang lainnya yang dikolaborasi guna penataan lingkungan kearah lebih baik.

Hasil dari artikel mengenai Implementasi Architecture For All Pada Pemanfaatan Ruang Terbuka Hijau Sebagai Ruang Tunggu Di Kantor Pemerintahan dengan Studi Kasus Kantor Walikota Jakarta Barat ini juga diharapkan mempunyai manfaat bagi beberapa pihak, baik untuk pemerintah sebagai penentu kebijakan maupun bagi pengembangan ilmu pengetahuan. Diharapkan juga menjadi informasi penting bagi para penentu kebijakan dalam penataan ruang, khususnya di kantor Pemerintahan Provinsi DKI Jakarta yang memiliki potensi untuk penataan aset bangunan-bangunan kantor pemerintahan. Hal ini dimaksudkan agar penataan RTH yang sudah ada bisa lebih dilengkapi sarana prasarananya sehingga fungsi ruang terbuka nantinya lebih maksimal dan masyarakat beraktifitas dengan nyaman, yang pada akhirnya dapat meningkatkan pelayanan kepada masyarakat. Selain itu diharapkan memberi Manfaat Bagi Ilmu Pengetahuan yang merupakan bagian penting dari tujuan penelitian ini karena dengan dilakukannya penelitian ini diharapkan wawasan ketajaman peneliti dalam memahami dan menyikapi permasalahan ruang tunggu dan ruang terbuka hijau semakin terasah dan menjadi salah satu informasi bagi masyarakat umum mengenai permasalahan bangunan kantor pemerintahan dan bagaimana cara mengatasinya khususnya yang berkaitan dengan fungsi bangunan, activity support dan perkembangan ruang terbuka. 


\section{REFERENSI}

Carr, Stephen, et.al,(1992). Public Space. Cambridge University Press,Cambridge.

Clare Cooper.(1998). All People Place. Design Guidelines For Urban Design Open Space, New York.

Darmawan, Edy. (2003). Teori dan Kajian Ruang Publik Kota. Badan Penerbit Universitas Diponegoro, Semarang.

Hakim, R. \& Utomo, H. (2003). Komponen Perancangan Arsitektur Lansekap. Jakarta, Bumi Aksara.

Haryadi B Setiawan. (1995). Arsitektur Lingkungan Dan Perilaku. Yogyakarta. Direktorat Jendral Pendidikan.

Krier Rob. (1979). Urban Space. USA. Rizolli Internasional Publication Ing.

Michelson, W. (1975). Behavior Research Method In Environmental Design ( Community Development Series). (8), Stroudsburg. Penn Dowen Hutchinson And Ross Inc.

Sommer, R and Sommer, B. (1980). Behavior Mapping. Practical Guide To Behavior Research, New York Oxford University Press.

Shirvani, Hamid. (1985). The Urban Design Process. Van Nostrand ReinHold Company, New York.

Spreiregen, Paul D. (1965). The Architecture of Towns and Cities. McGraw-Hill Book Company, New York.

Undang- Undang RI Nomor 26 Tahun 2007 tentang Penataan Ruang.

Undang- Undang RI Nomor 23 tahun 2014 tentang Pemerintah Daerah 